Cahiers $d u$ MONDE RUSSE

\section{Cahiers du monde russe}

Russie - Empire russe - Union soviétique et États indépendants

$62 / 4 \mid 2021$

Varia

\title{
Stephen V. BITTNER, Whites \& Reds. A History of Wine in the Lands of Tsar \& Commissar
}

\section{Timm Schönfelder}

\section{(2) OpenEdition}

\section{Journals}

Electronic version

URL: https://journals.openedition.org/monderusse/12985

DOI: 10.4000/monderusse. 12985

ISSN: $1777-5388$

\section{Publisher}

Éditions de l'EHESS

\section{Printed version}

Date of publication: 1 December 2021

Number of pages: 771-774

ISBN: 978-2-7132-2895-7

ISSN: $1252-6576$

\section{Electronic reference}

Timm Schönfelder, "Stephen V. BITTNER, Whites \& Reds. A History of Wine in the Lands of Tsar \& Commissar", Cahiers du monde russe [Online], 62/4 | 2021, Online since 01 December 2021, connection on 05 September 2022. URL: http://journals.openedition.org/monderusse/12985 ; DOI: https://doi.org/ 10.4000/monderusse. 12985

This text was automatically generated on 5 September 2022.

All rights reserved 


\title{
Stephen V. BITTNER, Whites \& Reds. A History of Wine in the Lands of Tsar \& Commissar
}

\author{
Timm Schönfelder
}

\section{REFERENCES}

Stephen V. BITTNER, Whites \& Reds. A History of Wine in the Lands of Tsar \& Commissar, Oxford : Oxford University Press, 2021, $272 \mathrm{p}$.

1 "Like a study of panda bears in Patagonia or dolphins in the Sahara, this book is devoted to what may seem an entirely incongruous topic - the history of wine and winemaking in the Russian Empire and the Soviet Union," comments Stephen Bittner in a slightly sardonic voice at the outset of his work. In his argument, the author connects wine domestication to the ambiguities of Russian imperialism with winemaking as the driving force behind an assimilatory process. While wine had been traded and consumed for centuries in the Kievan Rus', it was not until the reign of Peter the Great that it became preferred to mead. Soon, wine consumption was associated with the "nouveau riche'. The palate of Russian nobility grew more refined while the annexation of territories at the Black Sea saw a rise in the production of domestic wine. "For Russia's ambitious and upwardly mobile, wine became something that one learnt, a sign of cultural refinement that was brought into high polish, like proper French pronunciation" (p. 15). The underlying irony, however, is neither lost on Bittner, nor was it completely missed by the contemporaries: "The fact that many of the territories comprising the Russian Empire had long vinicultural histories - stretching back, in the case of Bessarabia, Crimea, and Georgia, many millennia - turned on its head the 'civilizing process' that had been part of Russian politics and culture since the time of Peter" (p. 58). 
2 During the $19^{\text {th }}$ century, Crimea evolved as one of the most productive regions for viniculture. Winemakers from all over Europe experimented with a vast array of varietals they tried to adapt to local conditions. This was helped by a growing range of scientific studies on soil quality, plant crossing, and meteorology. To many connoisseurs the promising results showed that the Russian Empire could compete with the famous Western European vinicultural regions. Mikhail Ballas, a Bessarabian nobleman of Greek origin, was one of the most famous wine-critics at the time. He authored an exhaustive six-volume work on Winemaking in Russia, published between 1895 and 1903. While he valued the quality of Crimean wine, he repeatedly criticized the Russian public's unrefined taste, which preferred adulterated drinks with a high alcohol content at a cheap price that were wrongly labeled as quality wines. Peasant producers, in turn, rather focused on wine as an unpretentious dietary staple to be consumed on a daily basis rather than a revelation of exalted taste and culture. While people like Ballas related the quality of a wine to the respective varietal used, the idea of "terroir" as the obscure combination of soil, climate, vine and winemaking also took form at the time - if only to describe negative influences on the taste.

3 The spread of European sorts and the resulting decline of indigenous ones made viniculture highly vulnerable. Consequently, the advent of grape phylloxera, the vine louse that caused the Great Wine Blight of the 1880s and 1890s, delivered a strong blow to the industry. It presumably spread from America to two thirds of the world's vineyards. While most European vines were prone to be destroyed by these aphids, the New World varietals were largely resistant to the pest they carried. As a countermeasure, imports of plants were strictly controlled, and a law on phylloxera treatment was passed in 1885 . Some natural scientists like the chairman to the Bessarabian Phylloxera Commission Aleksandr Kovalevskii even interpreted this as a Darwinist struggle for existence between the varietals. It was not before 1895 that the Russian administration switched from radical pesticide use to the well-tested practice of grafting French vines onto American rootstock.

According to Bittner, Russian viniculture was influenced by new Western scientific methods rather than it was rooted in local customs. This facilitated standardization and a rise in the production of cheaper, more accessible wines. This development was halted, however, by the introduction of a state monopoly on alcohol sales in 1894, stipulated by Sergei Witte. Not only did a relatively small group of merchants now control the wine trade, they also took the liberty of adulterating wines according to the presumed tastes of their costumers - much to the winemakers' dismay. One of their leading figures was Prince Lev Golytsin. In the 1890s, he was named chief vintner of such famed southern crown estates like Abrau-Diurso and Massandra by Tsar Alexander III. Golytsin became famous for his exquisite sparkling wines which won him a grand prix in Bordeaux in 1900. While this pinnacle of Russian viniculture proved to be short-lived, the new-found recognition and pride asked for a refined understanding of terroir, as Russian producers preferred to knock off famous Western brands and denominations - a persisting practice, considering Putin's champagne law that grants the internationally protected geographical indication to domestic "shampanskoe" while forcing traditional foreign producers to add the derogatory term "sparkling wine" to their labels.

While the 1914-Law on Grape Vine prohibited blending domestic and foreign wines, it allowed for the use of cane and beet sugar to enforce fermentation, the strengthening of wines with distilled grape alcohol to a certain degree, and the limited addition of 
sulfurous acid as a preservative. Following the 'continuum of crisis' of war and revolution, however, the 1920s again saw a largely unregulated wine-market. For Bittner, the 1917 Bolshevik coup d'état foreshadowed the future misfortune of Soviet Russia in all its drunken violence and unsophisticated brutality. Former crown estates like AbrauDiurso were transformed into sovkhozes. Golitsyn's heirs and other members of the vinicultural elite emigrated. Even though another state monopoly was short-lived, the Central Wine Trade Administration (Vintorg) became one of the most influential agents in commerce. Like its tsarist predecessors, it was complicit in adulterating wine with grain alcohol to satisfy costumers' demand for concoctions like bormotukha (from the verb 'to mumble') and chernila [ink]. "By the 1960s and 1970s, nearly all wine produced in the Soviet Union violated the 1914 wine purity law" (p.111), Bittner states. The artificially high alcohol content of up to 20 volume percent contributed to the rise of alcoholism.

Under Stalin's reign, patronage played a vital role for economic and physical survival. As a new elite of viticulturalists had not emerged, the USSR relied on formerly tsarist expertise. Thus, Anton Frolov-Bagreev's invention of the industrialized 'continuous method' to produce sparkling wine made Soviet champagne a more accessible symbol of the promised 'good life of socialism', which marked a strange continuance of capitalist ideals. During World War II, the vinicultural heartland was riddled by extensive fighting. Moldova, parts of Ukraine and Russia were temporarily occupied by axis forces. They took control of former crown estates like Abrau-Diurso - whose director had been charged with espionage and executed during the Stalinist purges in 1938 - and Massandra. It was not until the Khrushchev years that the Soviet spirits industry returned to the international fore and took part in competitions. While sales abroad were slow except for the increasingly popular Ukrainian champagne, mass production in the USSR profited from scientific and technological exchange. Soviet wines seldomly convinced international experts, however, as the example of the Californian wine-critic Maynard Amerine shows who lamented the predominantly poor quality during his repeated travels to the USSR in the 1960s and 1970s.

7 As the widely propagated ideal of kul'turnost' quietly appropriated formerly 'bourgeois' practices, it was considered instrumental in fostering a taste for 'quality' (i.e. unadulterated) wine in order to battle the rampant vodka- and bormotukha-fueled alcoholism of the Brezhnev era. However, the USSR's supply-oriented economy lacked the necessary incentives for the creation of truly fine wines. While Gorbachev's antialcohol campaign put viticulture into jeopardy, it also opened new paths for winemakers: in Georgia, where the production of adulterated wine played a minor role, vintners could now focus on higher quality as they were no longer forced to maximize output. Nonetheless, large parts of the industry collapsed during the turbulent 1990 s. Only in recent years did a rising urban connoisseurship and the competition of an open market offer new stimuli for high-quality winemaking. Bormotukha and the like became niche-phenomena. The long 'civilizing process' that began with the westward orientation of Peter the Great finally bore fruit. Yet as Bittner concludes, this happened "in the absence of empire, and without much state support at all" (p. 243) - as if to contradict the old elitist prejudice on the people's poor taste.

Bittner's history of winemaking is well-researched, clearly argued, and concisely written. More could have been said about the semantic switch of terroir in Russia, however, not least with regards to its supposed roots in Russian pedology. ${ }^{1}$ The same goes for the 
ecological implications of large-scale pesticide use in winemaking, which similarly plagues the vinicultural regions of France and other countries until today. While serving the reader with a well-ordered index, a bibliography is dearly missed. This nitpicking aside, Bittner's book is a lot like good wine itself: mature, balanced, rich on the palate and stimulating for the mind.

\section{NOTES}

1. Marion Demossier, "Terroir, Wine Culture, and Globalization: What Does Terroir Do to Wine?," Europe Now, September 5, 2018, https://www.europenowjournal.org/2018/09/04/terroir-wineculture-and-globalization-what-does-terroir-do-to-wine, accessed September 5, 2021. Cornelis van Leeuwen, Gerard Seguin, "The Concept of Terroir in Viticulture," Journal of Wine Research, 1 (2006): 1-10.

\section{AUTHORS}

\section{TIMM SCHÖNFELDER}

Leibniz Institute for the History and Culture of Eastern Europe (GWZO), Leipzig, Germany 